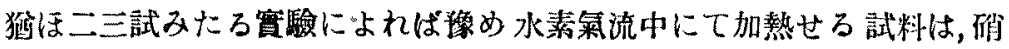
酸との作用に於ては水蒸氣々流中にて 加熱せる試料に類し, 空氮中にて 加 熱せる試料は濕潤なる空氣々流中にて加熱せる試料に類するもの、如し。

因に本石炭は $450{ }^{\circ} \mathrm{C}$ 以下の低温度に於ては單に加埶のみによりて殆んど

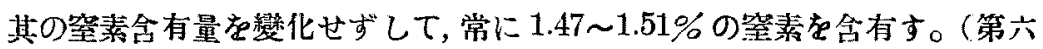

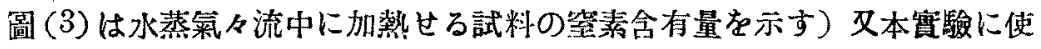
用せる程度の稀的酸は，石炭中の如何なる空素化合物をも㱠んと溶解せず， 從つて第十四表に於ける各試料の登素分より約 $1.5 \%$ 在除去せる數は,五

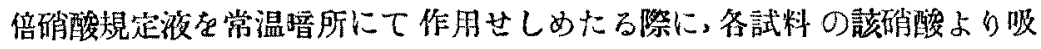
收せる辤素の量なっりとす。(未完)

\title{
研究短報交
}

\section{カオリンの化學成 分}

理學士瀨户國勝

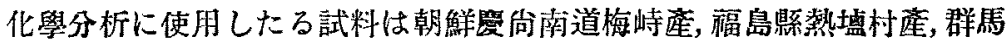

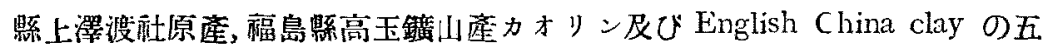

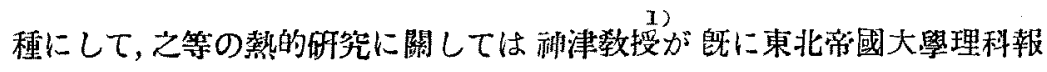
告第三集上に發表せられたり。余は之等試料に就き化學分析学行へり。其 結果は第一表に示すが如し。

1) S. Kôzu and M. Masuda, Sci. Rept. Tuhrku Imp. Univ, Ser. III. 3, 33-68, 1926. 
第一表に示さ吕つが如く，前記カオリンはその主成分なる 珪酸, 禁土, 水 分の外に，他の酸化物を不純物として含有すと雖もよくカオりンの化學成

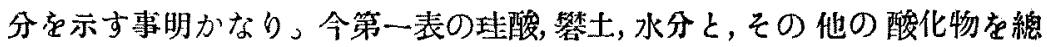
第 一 表

\begin{tabular}{|c|c|c|c|c|c|c|}
\hline & I. & II. & III. & IV. & v. & VI. \\
\hline $\mathrm{SiO}_{2}$ & 46.22 & 4575 & 45.68 & 45.46 & 45.67 & 46.50 \\
\hline $\mathrm{Al}_{2} \mathrm{O}_{3}$ & 38.91 & 39.27 & 39.49 & $39 \cdot 76$ & 39.29 & 39.50 \\
\hline $\mathrm{Fe}_{2} \mathrm{O}_{3}$ & 0.38 & 0.29 & 0.59 & 0.67 & ナシ & $\ldots \ldots$ \\
\hline $\mathrm{MgO}$ & 0.39 & 0.34 & 0.31 & ナ゙シ & 0.28 & ....... \\
\hline $\mathrm{CaO}$ & 0.62 & 0.35 & 0.74 & 0.29 & ナシ & ........ \\
\hline $\mathrm{Na}_{2} \mathrm{O}$ & 0.23 & 0.24 & 0.78 & 0.04 & 085 & ....... \\
\hline $\mathrm{K}_{2} \mathrm{O}$ & 0.38 & 0.37 & 0.21 & 0.72 & 0.34 & ........ \\
\hline $\mathrm{TiO}_{2}$ & ナン & tシ & 0.97 & ナシ & 0.16 & ....... \\
\hline $\mathrm{P}_{2} \mathrm{O}_{5}$ & 0.08 & 0.59 & ナシ & 0.21 & 0.09 & ....... \\
\hline $\mathrm{MDO}$ & 3 & & 痕跡 & 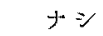 & 0.24 & \\
\hline $\mathrm{H}_{2} \mathrm{O}$ & 13.03 & 13.31 & 11.88 & 13.28 & 12.98 & 14.00 \\
\hline to:al & 100.24 & 100.51 & 100.15 & 100.43 & 99.90 & 100.00 \\
\hline
\end{tabular}

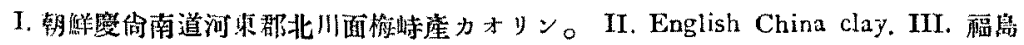

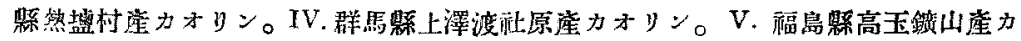
オリン。VIカオリンの理論的成分。

括して整基と假定し，此等四成分の分子比者第一表の重量百分率より計算 せりそその結果第二表に示さん。

\section{第 $=$ 表}

\begin{tabular}{|r|l|}
\hline I. & $\mathrm{SiO}_{2}: \mathrm{Al}_{2} \mathrm{O}_{3}: \mathrm{H}_{2} \mathrm{O}:$ bace $=2.0: 1: 1.9: 0.08$ \\
II. & $\mathrm{SiO}_{2}: \mathrm{Al}_{2} \mathrm{O}_{3}: \mathrm{H}_{2} \mathrm{O}:$ basc $=2.0: 1: 1.9: 0.08$ \\
III. & $\mathrm{SiO}_{2}: \mathrm{Al}_{2} \mathrm{O}_{3}: \mathrm{H}_{2} \mathrm{O}:$ base $=2.0: 1: 1,6: 0.14$ \\
IV. & $\mathrm{SiO}_{2}: \mathrm{Al}_{2} \mathrm{O}_{3}: \mathrm{H}_{2} \mathrm{O}:$ base $=1.9: 1: 1.9: 0.07$ \\
V. & $\mathrm{SiO}_{2}: \mathrm{Al}_{2} \mathrm{O}_{3}: \mathrm{H}_{2} \mathrm{O}:$ base $=2.0: 1: 1.9: 0.05$ \\
VI. & $\mathrm{SiO}_{2}: \mathrm{Al}_{2} \mathrm{O}_{3}: \mathrm{H}_{2} \mathrm{O}=2: 1: 2$ \\
\hline
\end{tabular}

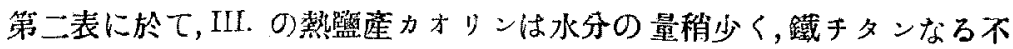
純物の量多し、これ試料に淡き穽赤蝎色を呈する物のためならん。神津教 授はカオリンを各温度に熱して脫水作用を受けたる物に就きて屈析率を見 
るに，その最高値は遊蔺 $\mathrm{Al}_{2} \mathrm{O}_{3}$ の夫より遥かに低く，その最低値は $\mathrm{SiO}_{2}$ の 夫に相當すと述べられ，從つてカオリンの脫水物中には遊部の $\mathrm{SiO}_{2} は$ 含ま

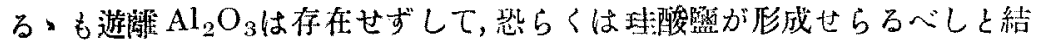
論せられたり。次にカオリンの脫水物と温度との關係を化學的に考祭せん に, $450^{\circ} \sim 650^{\circ} \mathrm{C}$ に於ては $\mathrm{Al}_{2} \mathrm{O}_{3} 2 \mathrm{SiO}_{2} 2 \mathrm{HI}_{2} \mathrm{O}$ は $\mathrm{Al}_{2} \mathrm{O}_{3} 2 \mathrm{SiO}_{2}+2 \mathrm{H}_{2} \mathrm{O}$ とな

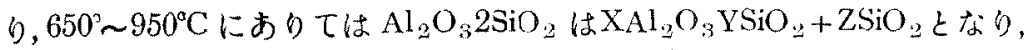
$950^{\circ} \mathrm{C}$ 以上に於ては $\mathrm{XAl}_{2} \mathrm{O}_{3} \mathrm{YSiO}_{2}+\mathrm{ZSiO}_{2}$ は $\mathrm{Al}_{2} \mathrm{O}_{3} \mathrm{SiO}_{2}+\mathrm{SiO}_{2}$ と成る にはおらざるか記して更に次の研究を待つ。

終に本研筑に際し御指導在晹りたる神津教授に染謝す。

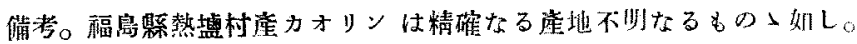

\section{評論及勧錄}

\section{結晶作用によりて生ずる壓力}

(火山活動及碾胍生成の一原因)

理學博士 利 津 俶 跍

岩獎の冷却によりて生ずる種々の現象は岩石成因學上研觉す心゙き重要な る問題の一なり。自然界に起り得る種々の條件の下に, 複雜なる成分を有 する岩漿の冷印固結する場合に生ずる現爱は,皆物理化學の法則に從はざ るベからず。然れも゙も之等の現象を睌知の物理化學の法則のみにて說明す

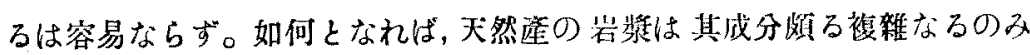
が上に其うちには，非拄發成分のみならず易挥發成分をも含み，且つそ等の

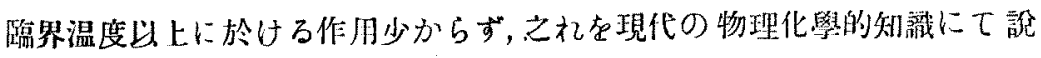

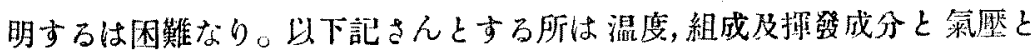
の關係にして, 殊に犹物成分の anhydrous fusion の温度に近き所に於ける 